American Journal of Environmental Sciences 5 (6): 753-758, 2009

ISSN 1553-345X

(C) 2009 Science Publications

\title{
Effects of Crude Oil and Spent Oil on Clarias garipinus: A Typical Marine Fish
}

\author{
A.M. Gbadebo, A.M. Taiwo and O.B. Ola \\ Department of Environmental Management and Toxicology, \\ University of Agriculture, PMB 2240, Nigeria
}

\begin{abstract}
Problem statement: Petroleum hydrocarbon and petroleum residue (i.e., spent oil) remains the foremost pollutants to the fish communities in various aquatic media-ponds, streams, rivers, creeks, coastal and marine environments through indiscriminate disposal of oil contaminated drilling muds, cutting and oil spillages. Approach: Also, the spent oil enters into aquatic media through run-off following unguided disposal. Both the petroleum hydrocarbon and spent oil, on getting to the water bodies spread fast and produce lethal, sub-lethal and even acute effect of petroleum hydrocarbon and spent oil on the fingerlings and other juvenile fishes. Results: Since this group of fish constitutes about $60 \%$ of the fish population in any aquatic medium, a green house study was carried out to assess the effects of crude oil and spent oil on fingerlings of Clarias garipinus-a typical marine fish. In this study, fingerlings of Clarias garipinus were exposed to 2-10\% concentration of crude oil and spent oil for $96 \mathrm{~h}$ period. Readings were taken every $24 \mathrm{~h}$. From concentration of $4-10 \%$, high mortality rate averaging 10 out of 10 fingerlings were recorded. Conclusion/Recommendations: The deaths were attributed to reduced dissolved oxygen and blockage of the water surface by the oils. Concentrations of $2 \%$ showed a reduced level of mortality, which even lapsed over the $96 \mathrm{~h}$ period. The mortalities were owed to impairment in neurologically dysfunction. Changes in physiological character such as changes in skin color and reduced locomotive actions were also observed.
\end{abstract}

Key words: Crude oil, spent oil, aquatic media, Clarias garipinus, Nigeria

\section{INTRODUCTION}

Petroleum hydrocarbon in its crude, refined or spent form has negative impact on both the human, animal and plant species ${ }^{[2,5]}$. The presence of crude and refined oils in the environment through spill most of the time is accidental while its deliberate introduction into the environment is often termed sabotage ${ }^{[16]}$. The situation is quite different in the case of the used oil called "spent oil" where its disposal in the environment is deliberate and indiscriminate with disregard to its pollution effect. Oil in the environment constitutes hazards which range from impairment to suppressed death $^{[14]}$. In the aquatic environments, evaluation of such hazards can be carried out using various toxicological substances in order to establish the various effects on the aquatic species. Such toxicological observation may be acute/lethal or chronic/sub-lethal. The lethal concentration of a substance is that urged to observe the short term effect over a test population. The median of the population tolerance curve, the $\mathrm{LC}_{50}$ (i.e., median lethal concentration) represents the most widely used of population tolerance. This is defined as the concentration that will kill $50 \%$ of the test population over a relatively short period of between 24 and $48 \mathrm{~h}$. Apart form noting the $\mathrm{LC}_{50}$ tolerance of a species, its physiological response can also be observed over this short period of exposure. Also the sub-lethal tests are the hour concentration of substances used to observe the long term effects over a test population. Unlike the lethal effect which is a survival test for the organism, sub-lethal effect indicates suppressed growth. Incidence of acute/lethal exposure of fish to oil spills has occurred over the years. Oil spillage has caused destruction of food resources ${ }^{[17]}$. However impacts of such oil spills on different aquatic organisms and species need to be assessed on a regular basis in order to ascertain its immediate effects and also predict its possible effects on physiological characteristics of these animals. The simplest of the laboratory toxicity test is one in which an organism especially the fish is placed in a standard

Corresponding Author: A.M. Gbadebo, Department of Environmental Management and Toxicology, University of Agriculture, PMB 2240, Nigeria 
tank of water of different dilutions for 48-96 $h^{[19]}$. The organisms are removed at the end of the period and mortality is recorded.

The choice of the test object depends on its geographic distribution, its availability in good number round the year and its sensitivity to the toxicant ${ }^{[9]}$. Fish is such an aquatic animal that possesses all these attributes. Since fisheries occupies a unique position in the agricultural sector in Nigerian economy and fish also constitute more than $40 \%$ of the animal protein consumed by the average Nigerians, there is need to investigate the pollution effect of crude oil, refinery effluents and spent oil on this class of aquatic animals. This study therefore, assessed the effect of crude oil and spent oil at varying concentration of between 0.25 and $2.5 \mathrm{mg} \mathrm{L}^{-1}$ on the fingerlings of Clarias garipinus-a typical marine fish over a period of $96 \mathrm{~h}$ in a green house experiment. The fingerlings has been chosen for this experiment since this group of fish constitutes about $60 \%$ of the fish population in any aquatic medium.

\section{MATERIALS AND METHODS}

This study measured the tolerance level of Clarias garipinus fingerlings at different concentration (i.e., toxicities) of both the crude and spent oils over a period of $96 \mathrm{~h}$.

The light bonny crude oil used in this study was obtained from an oil company in Port Harcourt while the used spent oil was collected from mechanic workshops in Camp area of Obantoko, Abeokuta. The fingerlings of Clarias garipinus with a mean weight of $7.9 \pm 0.9 \mathrm{~g}$ were obtained from a fish farm in Odeda and transported in a pond water to the department of Environmental Management and Toxicology Laboratory, University of Agriculture, Abeokuta. In the laboratory, the fish were acclimatized in a $30 \mathrm{~L}$ of aquarium prepared from dechlorinized tap water-a chemical similar to unpolluted river water for 14 days. The water was renewed every $24 \mathrm{~h}$ during acclimatization and the dissolved oxygen content was maintained by aerator. The actual volume of solution used during the experiment was $10 \mathrm{~L}$ while dilution was carried out using $0.25,0.5,1.0,1.5,2.0$ and $2.5 \%$ for both the crude oil and used spent oil respectively. The control was free of both oils. Prior to the experiment, the feeding of the fish was suspended for 2 days. During the experiment, observation was carried out every $24 \mathrm{~h}$ till the $96 \mathrm{~h}$ period of experiment after which living fingerling fish was observed. The numbers of dead fingerling fish were recorded at intervals of $24 \mathrm{~h}$. The percentage death was plotted against the dilution in order to observe the tolerance level of the fingerlings in both oils. Also the various $\mathrm{LC}_{50}$ of crude oil and spent oil were determined using arithmetic and graphical methods. The experiment which was replicated for the purpose of accuracy contained 10 fingerling fish in each aquarium with a control. The data generated were analyzed using basic statistical and graphical methods.

\section{RESULTS}

The results obtained from this experiment are shown in Table 1 and 2. The experiment with the spent oil shows a progressive increase in the mortalities of the fingerlings fish over the period of 24, 48, 72 and $96 \mathrm{~h}$ respectively and a proportionate increase in mortalities with increase in concentrations. However, the mortality was at its peak and also constant at concentrations of between 1.50 and $2.50 \%$ of spent oil for 48,72 and $96 \mathrm{~h}$ timing. After the $96 \mathrm{~h}$ period, the $\mathrm{LC}_{50}$ determined from Table 1c using arithmetic graph methods was $40.3 \mathrm{~mL}$ (i.e., $\mathrm{LC}_{50}=40.3 \mathrm{~mL}$ ) for spent oil. Similarly, in the crude oil experiment, there was no mortality(i.e., mean-mortality $=0.0$ ) at all in the concentration levels within the first $24 \mathrm{~h}$ as in the spent oil and also, no mortality was recorded at concentration of 0.25 and $0.50 \%$ for both 48,72 and $96 \mathrm{~h}$ periods. However, the mortality rate of about $25.0 \%$ was recorded at concentration levels of $1.00-2.00 \%$ in the $48 \mathrm{~h}$ which rose to $38.3 \%$ in the $72 \mathrm{~h}$ and $65.0 \%$ in the $96 \mathrm{~h}$ period respectively. Unlike in the spent oil, mortality was constant at $2.50 \%$ concentration level of crude oil. Also, after $96 \mathrm{~h}$ period, the $\mathrm{LC}_{50}$ determined from Table 2c using arithmetic graph method was $20.6 \mathrm{~mL}$ (i.e., $\mathrm{LC}_{50}=20.6 \mathrm{~mL}$ ) for crude oil, which was actually low when compared with that of spent oil. Due to low solubility and density of the spent oil, it spreads fast on the surface of the water and drastically inhibited the oxygen penetration. The low oxygen level in the experimental aquarium caused both the physical and metabolic stress in the fingerling fish and increased their sensitivity to the oil toxicants ${ }^{[4]}$. According to Lloyd $^{[12]}$, most aquatic fish respond to organic toxicity when the oxygen saturation is below $60 \%$.

\section{DISCUSSION}

In this study the experimental fish exhibited a very low tolerance to the effect of the spent oil polluted water as the cumulative mortality rose from $25.0-72.1 \%$ within the 24-96 $\mathrm{h}$ period. Mortality could also be a function of physiological effects other than sag in dissolved oxygen curve in the aquarium, the continuous stay of the fish at the bottom of the experimental aquarium during the exposure period was an indication of their low response to stimuli. In a natural marine ecosystem, such an hour response to stimuli will increase the susceptibility of the fish to predation. 
Am. J. Environ. Sci., 5 (6): 753-758, 2009

Table 1a: Experiment conducted at 24, 48, 72 and $96 \mathrm{~h}$ for fingerlings of Clarias gariepanus in spent oil

\begin{tabular}{|c|c|c|c|c|c|c|c|c|c|c|c|c|}
\hline \multirow[b]{2}{*}{$\begin{array}{l}\text { Concentration } \\
(\mathrm{mL})\end{array}$} & \multicolumn{3}{|l|}{$24 \mathrm{~h}$} & \multicolumn{3}{|l|}{$48 \mathrm{~h}$} & \multicolumn{3}{|l|}{$72 \mathrm{~h}$} & \multicolumn{3}{|l|}{$96 \mathrm{~h}$} \\
\hline & $\begin{array}{l}\text { Mean } \\
\text { mortality }\end{array}$ & SD & $\begin{array}{l}\text { Mortality } \\
(\%)\end{array}$ & $\begin{array}{l}\text { Mean } \\
\text { mortality }\end{array}$ & SD & $\begin{array}{l}\text { Mortality } \\
(\%)\end{array}$ & $\begin{array}{l}\text { Mean } \\
\text { mortality }\end{array}$ & SD & $\begin{array}{l}\text { Mortality } \\
(\%)\end{array}$ & $\begin{array}{l}\text { Mean } \\
\text { mortality }\end{array}$ & SD & $\begin{array}{l}\text { Mortality } \\
(\%)\end{array}$ \\
\hline 25 & 0.0 & 0.00 & 0.0 & 0.0 & 0.00 & 0.0 & 0.5 & 0.71 & 5.0 & 2.5 & 0.71 & 25.0 \\
\hline 50 & 0.0 & 0.00 & 0.0 & 1.5 & 2.12 & 15.0 & 3.5 & 2.12 & 35.0 & 6.0 & 2.83 & 60.0 \\
\hline 100 & 3.0 & 1.41 & 30.0 & 7.5 & 0.71 & 75.0 & 9.0 & 0.00 & 90.0 & 9.0 & 0.00 & 90.0 \\
\hline 150 & 7.5 & 0.71 & 75.0 & 9.5 & 0.71 & 95.0 & 10.0 & 0.00 & 100.0 & 10.0 & 0.00 & 100.0 \\
\hline 200 & 9.5 & 0.71 & 95.0 & 10.0 & 0.00 & 100.0 & 10.0 & 0.00 & 100.0 & 10.0 & 0.00 & 100.0 \\
\hline 250 & 10.0 & 0.00 & 100.0 & 10.0 & 0.00 & 100.0 & 10.0 & 0.00 & 100.0 & 10.0 & 0.00 & 100.0 \\
\hline
\end{tabular}

Table 1b: Mortalities of fingerlings on various concentration of spent oil

\begin{tabular}{|c|c|c|c|c|c|c|c|c|}
\hline \multirow{3}{*}{$\begin{array}{l}\text { Concentration } \\
(\mathrm{mL})\end{array}$} & \multicolumn{8}{|c|}{ Cumulative mortality } \\
\hline & \multicolumn{2}{|c|}{$24 \mathrm{~h}$} & \multicolumn{2}{|c|}{$48 \mathrm{~h}$} & \multicolumn{2}{|c|}{$72 \mathrm{~h}$} & \multicolumn{2}{|c|}{$96 \mathrm{~h}$} \\
\hline & A & $\mathrm{B}$ & A & $\mathrm{B}$ & A & $\mathrm{B}$ & A & B \\
\hline 25 & 0 & 0 & 0 & 0 & 1 & 0 & 2 & 3 \\
\hline 50 & 0 & 0 & 0 & 3 & 2 & 5 & 4 & 8 \\
\hline 100 & 4 & 2 & 8 & 7 & 9 & 9 & 9 & 9 \\
\hline 150 & 9 & 10 & 9 & 10 & 10 & 10 & 10 & 10 \\
\hline 200 & 7 & 8 & 10 & 10 & 10 & 10 & 10 & 10 \\
\hline 250 & 10 & 10 & 10 & 10 & 10 & 10 & 10 & 10 \\
\hline Control A & 0 & 0 & 0 & 0 & 0 & 0 & 0 & 0 \\
\hline Control B & 0 & 0 & 0 & 0 & 0 & 0 & 0 & 0 \\
\hline
\end{tabular}

Table 1c: Percentage mortalities of fingerlings on various percentage concentration of spent oil

\begin{tabular}{lllll}
\hline $\begin{array}{l}\text { Concentration } \\
(\mathrm{mL})\end{array}$ & $\begin{array}{l}\text { Percentage } \\
\text { concentration }\end{array}$ & $\begin{array}{l}\text { Concentration } \\
\text { in dilution }\end{array}$ & Mortality & $\begin{array}{l}\text { Percentage } \\
\text { mortality }\end{array}$ \\
\hline 25 & 0.25 & 1.400 & $2.3 / 10$ & 25 \\
50 & 0.50 & 1.200 & $6 / 10$ & 60 \\
100 & 1.00 & 1.100 & $9 / 10$ & 90 \\
150 & 1.50 & 1.660 & $10 / 10$ & 100 \\
200 & 2.00 & 1.500 & $10 / 10$ & 100 \\
250 & 2.50 & 1.400 & $10 / 10$ & 100 \\
\hline
\end{tabular}

$\mathrm{LC}_{50}=40.3 \mathrm{~mL}$

The diagrams in (Fig. 1) indicates that mortality occur at every concentration of the spent oil. The percentage of the mortality increases steadily until it became constant at a concentration of between 1.50 and $2.50 \%$.

In the case of the crude oil, the toxicity was not felt by the fingerling fish immediately, possibly because of the high density and solubility of the crude oil. This probably resulted in an incomplete spreading of the oil over the surface of the water thereby enhance availability of oxygen to the aquarium than that of the spent oil. In this study, the experimental fish show a preferential tolerance to crude oil toxicity than the spent oil toxicity. Muller ${ }^{[15]}$ has observed that fish has tendency of excreting foreign compounds such as hydrocarbon compounds. The fish is however left with little energy to carry out other activities hence leading to death. The non-observance of death effect of the crude oil on the fingerling fish at concentration of 0.25 and $0.50 \%$ in this study (Fig. 1b) is an evidence of low clinical sign of toxicity. However, the toxicity of the crude oil was found to increase with time probably due to various factors such as solubility and photoreactions.

It was also discovered that at every concentration of the spent oil and crude oil, the fish showed some clinical behaviors which include restlessness, air gulping, leaping, erratic swimming and stressful behavior. This is justified by the findings of Rhodes et al. ${ }^{[18]}$ that lethality should not be the only dose-related system effect that would justify a classification and more use would and could be made of the induced clinical signs, i.e., the use of quantitative judgments based on the final conclusion.

Toxicity in this respect may be considered to be capacity of a chemical or substance causing injury, hazards and probability of injury occurring ${ }^{[1]}$. The percent mortality versus concentration curve in Fig. 1 for both spent oil and crude oil follows a sigmoid pattern $^{[18]}$ except the LC50 of the crude oil at $24 \mathrm{~h}$. The reason for this may be due to the length of time required for crude oil to spread and dissolve in water.

It can be deduced from Fig. 1 that percent mortality increases with concentrations in both the spent oil and crude oil. In this case percent mortality versus concentration curve for $24 \mathrm{~h}$ in crude oil there is no sign of toxicity. The reason is that, the concentration of the crude oil to sufficiently overcome inherent capacity within biological system to elicit change is not yet attained ${ }^{[6,11]}$.

The toxicity curve in Fig. 2 shows that for both spent and crude oil, there is inverse relationship between lethal concentration and time i.e., as concentration decreases time increases. The implication of this is that even at mild concentration, the spent oil could cause the lethality on fish as time of exposure increases. Studies have shown that the severity of response is established by dose-effects (the relationship between dose and the magnitude of defined biological effects either in individual or in a population sample). Toxic effects depend on the concentration and duration of exposure of the toxicants to specific target sites ${ }^{[10]}$. For crude oil, the trend was different; lethal concentration first increases with time before it begins to fall (Fig. 2b). 
Am. J. Environ. Sci., 5 (6): 753-758, 2009

Table 2a: Experiment conducted at 24, 48, 72 and $96 \mathrm{~h}$ for fingerlings of Clarias gariepanus in crude oil

\begin{tabular}{|c|c|c|c|c|c|c|c|c|c|c|c|c|}
\hline \multirow[b]{2}{*}{$\begin{array}{l}\text { Concentration } \\
(\mathrm{mL})\end{array}$} & \multicolumn{3}{|l|}{$24 \mathrm{~h}$} & \multicolumn{3}{|l|}{$48 \mathrm{~h}$} & \multicolumn{3}{|l|}{$72 \mathrm{~h}$} & \multicolumn{3}{|l|}{$96 \mathrm{~h}$} \\
\hline & $\begin{array}{l}\text { Mean } \\
\text { mortality }\end{array}$ & SD & $\begin{array}{l}\text { Mortality } \\
(\%)\end{array}$ & $\begin{array}{l}\text { Mean } \\
\text { mortality }\end{array}$ & SD & $\begin{array}{l}\text { Mortality } \\
(\%)\end{array}$ & $\begin{array}{l}\text { Mean } \\
\text { mortality }\end{array}$ & SD & $\begin{array}{l}\text { Mortality } \\
(\%)\end{array}$ & $\begin{array}{l}\text { Mean } \\
\text { mortality }\end{array}$ & SD & $\begin{array}{l}\text { Mortality } \\
(\%)\end{array}$ \\
\hline 25 & 0.0 & 0.00 & 0.0 & 0.0 & 0.00 & 0.0 & 0.0 & 0.00 & 0.0 & 0.0 & 0.00 & 0.0 \\
\hline 50 & 0.0 & 0.00 & 0.0 & 0.0 & 0.00 & 0.0 & 0.0 & 0.00 & 0.0 & 0.0 & 0.00 & 0.0 \\
\hline 100 & 0.0 & 0.00 & 0.0 & 1.5 & 0.71 & 15.0 & 5.0 & 1.41 & 50.0 & 9.0 & 0.00 & 90.0 \\
\hline 150 & 0.0 & 0.00 & 0.0 & 5.5 & 0.71 & 55.0 & 7.5 & 0.71 & 75.0 & 9.0 & 0.00 & 100.0 \\
\hline 200 & 0.0 & 0.00 & 0.0 & 6.5 & 0.71 & 65.0 & 8.5 & 0.71 & 85.0 & 10.0 & 0.00 & 100.0 \\
\hline 250 & 0.0 & 0.00 & 0.0 & 9.5 & 0.71 & 95.0 & 10.0 & 0.00 & 100.0 & 10.0 & 0.00 & 100.0 \\
\hline
\end{tabular}
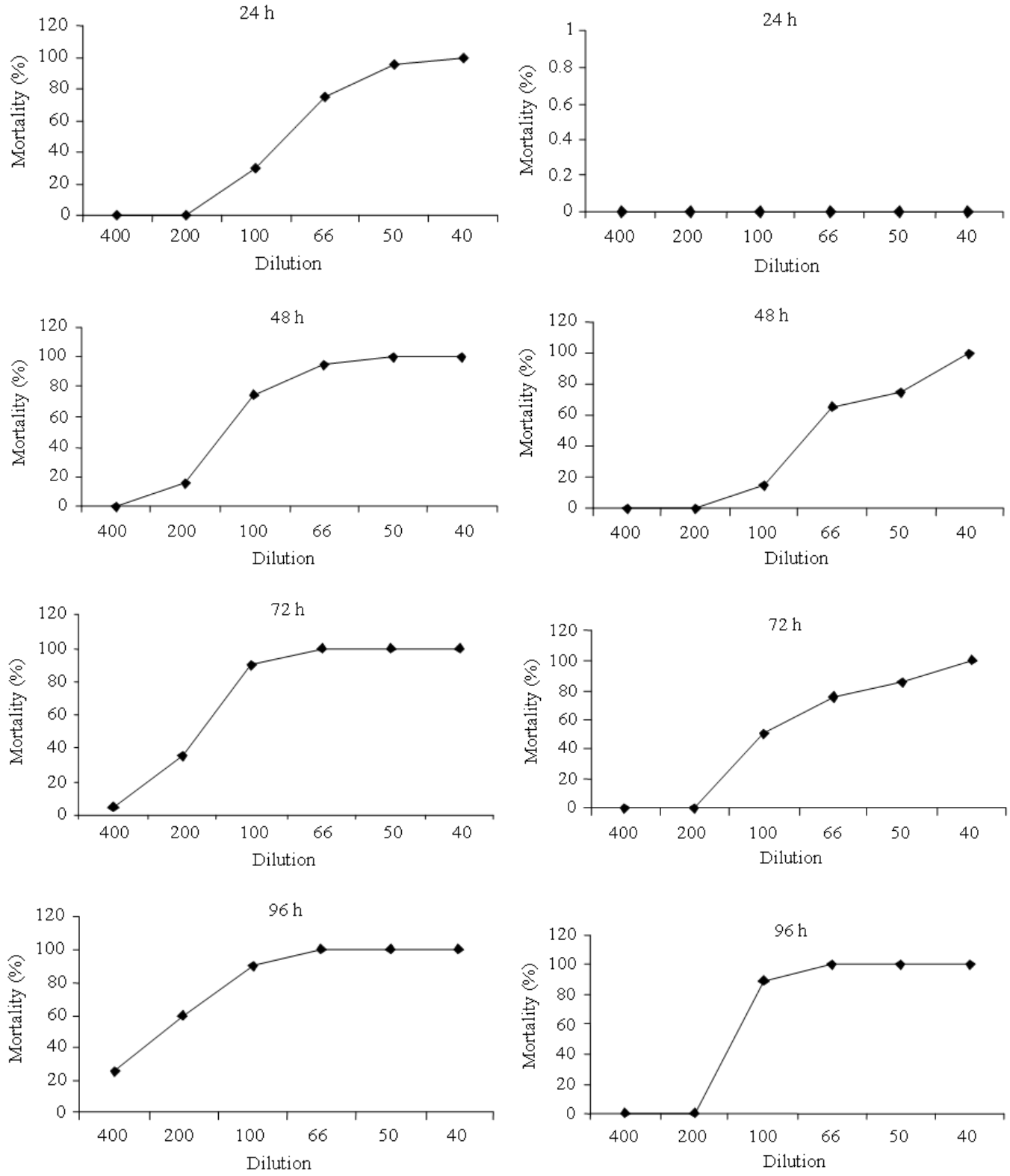

(a)

(b)

Fig. 1: Comparative Mortality plots of Fingerlings of Clarias gariepinus in both spent and crude oils at different hours. (a) spent; (b) Crude oil 
Am. J. Environ. Sci., 5 (6): 753-758, 2009
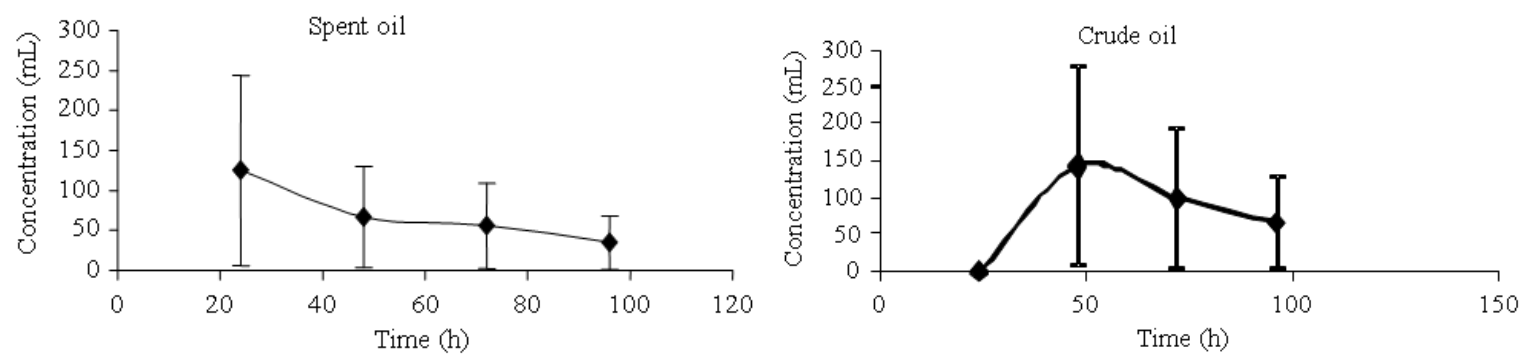

Fig. 2: Toxicity Curve of Spent and Crude oils on fingerlings of Clarias gariepinus at $95 \%$ confidence limits

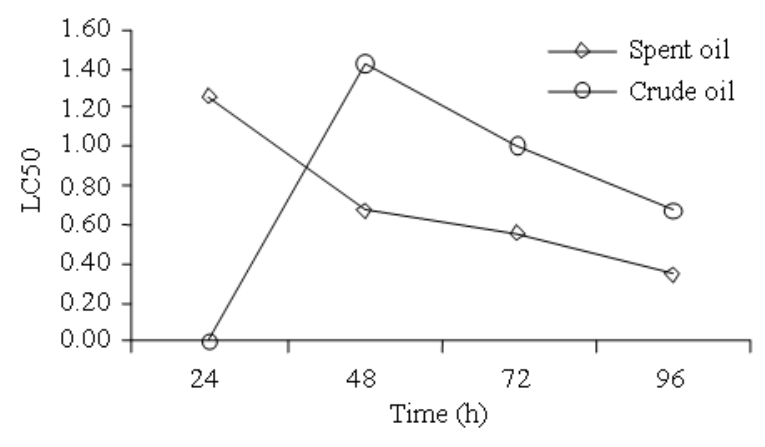

Fig. 3: Comparison of toxicities of both spent and crude oil

Table 2b: Mortalities of fingerlings on various concentration of crude oil

\begin{tabular}{|c|c|c|c|c|c|c|c|c|}
\hline \multirow{3}{*}{$\begin{array}{l}\text { Concentration } \\
(\mathrm{mL})\end{array}$} & \multicolumn{8}{|c|}{ Cumulative mortality } \\
\hline & \multicolumn{2}{|c|}{$24 \mathrm{~h}$} & \multicolumn{2}{|c|}{$48 \mathrm{~h}$} & \multicolumn{2}{|c|}{$72 \mathrm{~h}$} & \multicolumn{2}{|c|}{$96 \mathrm{~h}$} \\
\hline & A & B & A & B & A & B & A & B \\
\hline 25 & 0 & 0 & 0 & 0 & 0 & 0 & 0 & 0 \\
\hline 50 & 0 & 0 & 0 & 0 & 0 & 0 & 0 & 0 \\
\hline 100 & 0 & 1 & 2 & 1 & 4 & 6 & 9 & 9 \\
\hline 150 & 0 & 0 & 5 & 6 & 7 & 8 & 9 & 9 \\
\hline 200 & 0 & 0 & 7 & 6 & 9 & 8 & 10 & 10 \\
\hline 250 & 0 & 0 & 9 & 10 & 10 & 10 & 10 & 10 \\
\hline Control A & 0 & 0 & 0 & 0 & 0 & 0 & 0 & 0 \\
\hline Control B & 0 & 0 & 0 & 0 & 0 & 0 & 0 & 0 \\
\hline
\end{tabular}

Table 2c: Percentage mortalities of fingerlings on various percentage concentration of crude oil

\begin{tabular}{llllc}
\hline $\begin{array}{l}\text { Concentration } \\
(\mathrm{ml})\end{array}$ & $\begin{array}{l}\text { Percentage } \\
\text { concentration }\end{array}$ & $\begin{array}{l}\text { Concentration } \\
\text { in dilution }\end{array}$ & Mortality & $\begin{array}{l}\text { Percentage } \\
\text { mortality }\end{array}$ \\
\hline 25 & 0.25 & 1.400 & $0 / 10$ & 0 \\
50 & 0.50 & 1.200 & $0 / 10$ & 0 \\
100 & 1.00 & 1.100 & $9 / 10$ & 90 \\
150 & 1.50 & 1.660 & $10 / 10$ & 100 \\
200 & 2.00 & 1.500 & $10 / 10$ & 100 \\
250 & 2.50 & 1.400 & $10 / 10$ & 100 \\
\hline
\end{tabular}

$\mathrm{LC}_{50}=20.6 \mathrm{~mL}$

By comparing toxicity between spent and crude oil in Fig. 3, it reveals that the toxicity of spent oil and the consequent effects on the fish was higher than that of crude oil. While the lethal concentration decreases with time in spent oil from the 24-96 h; for crude oil lethal concentration increases in the first $24 \mathrm{~h}$ of the experiment and then begins to fall. The reason for this may be due to the solubility of spent oil, which is more soluble than the crude oil. Moreover, spent oil may contain additional toxicants especially the heavy metals, which makes it more toxic than the crude oil. According to Mance ${ }^{[13]}$, Zinc is known to cause gill damage, reduced growth and kidney damage in fish. Lead causes spinal curvature, muscular atrophy, kidney disfunctioning, anemia, liver and blood cell damage ${ }^{[8]}$. Cadmium has been reported toxic to fish by causing nervous system damage and kidney disfunctioning ${ }^{[7]}$. On the other hand it will take some time for crude oil to dissolve its toxic constituents in the water to cause Fishkill.

\section{CONCLUSION}

The conclusion of this study is that petroleum oil, whether crude or spent oil is very toxic to fish (i.e., Clarias garipinus fingerlings). This assertion is supported by the fact that the water-soluble components of crude oil are toxic and could affect the survival and metabolism of aquatic animals including fish ${ }^{[3]}$. However, the study also revealed that spent oil produced more toxic effects on the Clarias fingerlings at every concentration than that of crude oil. This attributes may be connected with the fact that spent oil probably contains additional toxic substance than crude oil. Persistent release of both the crude and spent oils into the aquatic environment in the nation may drive the fish (including Clarias garipinus) into gradual extinction.

Considering the economic importance of fish as a source of food and income earnings; the indiscriminate disposal of both crude oil and spent oil through spills, negligence of the oil companies' activities and vandals in the nation's aquatic environment should be controlled through proper monitoring. 


\section{REFERENCES}

1. Barnes, J.M., 1963. Toxic hazards from drugs. J. Pharmacol., 15: 75-91. PMID: 141062

2. Clark, R.B., 1992. Marine Pollution. 3rd Edn., Oxford University Press, New York, ISBN: 10: 0198792921, pp: 28-48.

3. Cote, R.P., 1976. The effects of petroleum industry liquid wastes on aquatic life with special emphasis on the Canadian environment. National Research Council Canada, Canada.

4. Davies, H.S., 1995. Culture and Diseases of Fishes. Berkeley California, University of California Press, ISBN: 0-520-00293-8, pp: 332.

5. De Song, E., 1980. The effect of crude oil spill on cereals. Environ. Pollut., 22: 187-96. DOI: 10.1016/0143-147(80) 90013-6

6. Dinman, B.D., 1972. Non-concept of no-treshold: Chemicals in the environmental. Science, 175: 495-497. DOI: 10.1126/science.175.4021.495

7. Dunstan, W.M., H.L. Windom and G.L. Mcintine, 1975. The role of Spatina alterflora in the flow of lead, cadimuim and copper through salt march ecosystem in prosymp. Mineral Cycling in the Southeastern Ecosystem, pp: 250-256.

8. Eisler, R.L., 1988. Lead hazards to fish, wildlife and invertibtrates a synoptic review. US fish and wildlife service, US Determent of Interior, Biological Report, 85: 1-14.

9. ELFAC., 1983. Revised report on fish toxicity testing procedures. ELFAC Technical Paper, 24: 38. ISBN: 9251013152.

10. Gehring, P.J. and K.S. Rao, 1981. Toxicology Data Extrapolation. In: Patty's Industrial Hygiene and Toxicology, 3rd Edn., Wiley, New York, ISBN: 10: 0471530654, pp: 567-594.

11. Hermann, E.R., 1967. Threshold prediction and characteristics of log-normal phenomena. Environ. Res., 1: 359-369. DOI: 10:1016/00139351(67)90025-4. PMID-56022922

12. Lylod, R., 1961. Effects of dissolved oxygen concentration on the toxicity of several poisons to Rainbow trout (Salmon gairdneri Richardson). J. Exp. Biol., 38: 447-455.
13. Mance, G., 1987. Pollution Threat of Heavy Metals in Aquatic Environment. Elsevier Science Publishing Co., London. ISBN: 10: 1851660399.

14. Moore, J.W. and S. Ramamoorthy, 1984. Organic Chemicals in Natural Waters. Springer Verleap Inc., New York, ISBN: 10: 0387960341, pp: 116-135.

15. Muller, T.G., 1967. Living in the Environment; Concept, Problems and Alternatives. Wads Wart Publishing Company, ISBN: 0534003478

16. Nwankwo, J.N., 1983. Oil spills in Nigeria: Causes, effects and remedies. Proceedings of the National Conference on Development and Environment, NISER, Ibadan, pp: 47.

17. Percival, S.M. and P.R. Evans, 1997. Factors affecting the exploitation of a seasonally declining food resource. Ibis, 139: 121-128.

18. Rhodes, C., M. Thomas and J. Athus, 1993. Principle of Testing for Acute Toxic Effects. In: General and Applied Toxicology, Ballantyne, B., T. Marrss and P. Turner (Eds.). M Stockton Press, UK., ISBN: 10: 1561591076, pp: 51-89.

19. Ward, G.S. and P.R. Parrish, 1982. Manual of methods in aquatic environment research Part 6. Toxicity Tests. FAO Fisheries Technical Paper, ISBN: 92-5-103136-3, pp: 24. 